\title{
Rigid Spine Muscular Dystrophy 1
}

National Cancer Institute

\section{Source}

National Cancer Institute. Rigid Spine Muscular Dystrophy 1. NCI Thesaurus. Code

C126691.

An inherited muscular dystrophy caused by mutations in the SEPN1 gene. It is

characterized by severe limitation in flexion of the dorsolumbar and cervical spine, due to contracture of the spinal extensors. It leads to loss of movement of the spine and the thoracic cage. 